Article

\title{
Building Peace through Journalism in the Social/Alternate Media
}

\author{
Rukhsana Aslam \\ Pacific Media Centre, Auckland University of Technology, Auckland 1010, New Zealand; \\ E-Mail: rukhsanaaslamkhan@hotmail.com
}

Submitted: 10 June 2015 | Accepted: 27 October 2015 | Published: 18 February 2016

\begin{abstract}
Social media networks are rapidly rewriting the traditional principles and protocols of war and conflict reporting. This paper endorses the argument that with the help of new media technologies, journalists can enhance the peacebuilding efforts in societies and communities. Their writings in the alternate media can provide 'compelling form of engagement' between the audiences and the people affected in the areas of violent conflict. But, the paper further argues, this requires a broadening of the orthodox model of journalistic objectivity that has so far been in place. It examines the possibilities of new models in the light of the existing journalism paradigms as argued by scholars including Galtung and Ruge (1965), Lynch and McGoldrick (2005), Shinar (2007), Hackett (2011) and Shaw (2011). It concludes on the need to have a model that is 'a more natural fit' for the $21^{\text {st }}$ century by giving journalists the 'flexibility' to enable people to make their own judgments as to where the truth lies; and to open up the possibilities for dialogue and engagement in conflict resolution.
\end{abstract}

\section{Keywords}

alternate media; challenger paradigm; conflict resolution; new journalism models; peacebuilding; peace journalism; social media

\section{Issue}

This article is part of the issue "Peacebuilding in the Age of New Media", edited by Vladimir Bratic (Hollins University, USA).

(C) 2016 by the author; licensee Cogitatio (Lisbon, Portugal). This article is licensed under a Creative Commons Attribution 4.0 International License (CC BY).

\section{Introduction}

New media, social media and alternate media are the terms used intermittently to explain the technological changes that have revolutionised the information gathering, news making and its distribution across the boundaries. Because of their increased overlapping of the content and functions, these platforms are fast becoming an alternate platform for distributing news and information (Hackett, 2011; Keeble, 2010; Matheson \& Allan 2010; Newman, 2011; van Dijck \& Poell, 2013).

Not only is the online daily coverage of news made available by almost all major media organisations, newspapers and televisions channels, they also have Twitter feeds and Facebook pages (Newman, 2011). Smaller independent media organisations use it as a major source to publish news, and journalists have their blogs, twitters and Facebook accounts to express their opinion and views. The rise of 'citizen journalism and mass-self communication' is now seen as a direct alternative to 'journalism's traditional role or mission, its public responsibilities' (Allan, 2007). According to AOL News editor in chief, Lewis D'Vorkin, (as cited by Allan, 2007): 'the world is turning to the fastest growing news team-citizen journalists-to get a human perspective through the eyes of those who lived or experienced the news as it unfolds'.

Alia goes to the extent of calling blogging the new journalism, able to cross geographic, cultural and political borders and help build community, transcending the limits imposed by attitudes, policies, and governments of the regions and countries where they reside' (Alia, 2010, p. 136). Moreover, 'Twitter users are beginning to find their way into the start-system of mass media alongside media celebrities' whereby journalists are treating tweets from celebrities or politicians as 'quotes' (Lesage \& Hackett, 2013, p. 7). The result is that these platforms 'are increasingly accepted as legit- 
imate standards to measure and mark people and ideas; these rankings are then amplified through mass media and in turn reinforced by users through social buttons such as following and liking' (p. 7).

Social media is also a major source for the whistleblowers, e.g. the WikiLeaks, which in many instances has attracted the media's attention world over. Privately uploaded videos on media outlets such as YouTube have many-a-times attracted mainstream media's attention. According to Matheson and Allan (2010), the citizen dispatches relayed in these spaces 'reveal their potential to narrow the distance that otherwise allows distant publics to ignore their plight' ( $p$. 188). Even the indigenous media in countries such as Canada, Japan, USA, Australia and Greenland, has found audiences across the globe (Alia, 2010). This signifies the cross-over roles of the mainstream, social and new media especially in cases where the stories have been overlooked or avoided by the mainstream media. Hence, the terms 'social media', 'new media' and 'alternate media' are broadly referred to in the paper as social media platforms and networks, and are treated as a given social reality or environment in which the journalists have to operate in order to write and disseminate news on conflict, without going into their ideologies, complexities, politics or dynamics.

This article focusses more on looking at the possibilities available for the journalists to play a more positive role in conflict situations and help build peace in societies in the new age media. It argues for the need to have a 'broader model of journalism' to achieve that goal and discusses its implications for those who practice the profession in the light of existing alternate models. It concludes that any journalism model that can provide 'a natural fit for the $21^{\text {st }}$ century' must have the flexibility and creativity to make full use of the technological advancements that characterise the age of new media. At the same time, there needs to be a cohesive and 'synergised media strategy' between the journalists and other media professionals, researchers, academics, peace workers and communities if they are to make a positive social change.

\section{Peace and Conflict Reporting in Social Media Networks}

Social media networks are 'rapidly rewriting the principles and protocols of war and conflict reporting', argue Matheson and Allan (2010, p. 187) in their study of four conflicts in the year 2008. The study consisted of the social media responses to Mumbai terrorist attacks in India; street protests in Greece; the final government's push against the Tamil Tigers in Sri Lanka and the Israeli assault on Gaza. They conclude that 'collaborative approaches to news gathering offer compelling forms of engagement and immediacy'. Although it is acknowledged that such information is 'also prone to inaccuracy, with key "facts" lacking verification or corroboration' (p. 187) as in the cases of Mumbai and Greece, tweeting had echoes of 'rumour and prejudice'. Yet, the authors also point out that in situations like Sri Lanka and Gaza, 'social networks fill silences created by censorship and suppression' (p. 187). In their opinion, the fact that social networks are being used to 'make connections across diasporas, to mobilise support and to build complex global spaces outside those established by news organisations and states[,] open up new distinctive forms of communication which journalism cannot afford to ignore' (p. 187).

Newman (2011) in his report Mainstream Media and the Distribution of News in the Age of Social Discovery gave three case studies to demonstrate how social media platforms are changing the production, distribution and discovery of news. One of them is the news of the death of Osama Bin Laden when the American forces raided his house in Abbottabad in Pakistan in May 2011. The first tweet was posted by Shoaib Akhtar, a Pakistani IT consultant on a holiday in the mountainous city of Abbottabad and feeling annoyed at the sound of the hovering helicopter in the area at 1am Pakistan local time. By the time Akhtar realised what was going on, he had become 'the guy who liveblogged the Osama raid without knowing it' (Newman, 2011, p. 30):

By that time he'd gathered almost 100,000 followers for his Twitterstream and not just a network hub of information about events in Abbottabad but a story in his own right. He spent much of the few days talking to the world's press and posting pictures of them setting up their satellite positions near his home. (Newman, 2011, p. 30)

In Britain, records Newman, the social monitoring tool Trendsmap showed that 'BBC stories were consistently the most shared on Twitter throughout the day, and BBC log files showed almost 400,000 referrals from Facebook and Twitter to the top stories about the event' (p. 32). Back in the United States the story also emerged first through Twitter and went viral, records Newman. New York based company Social Flow mapped how the story spread by analysing 15 million tweets. Within one minute, it reported, the first tweet was resent eighty times and from there it went viral ( $p$. 31). Many people tweeted that they had first got the news on Twitter or Facebook, then checked it on News App on their mobile and then switched to the TV.

Jeff Jarvis, American journalism professor, summed up the change in the news distribution of Osama's death in these words:

The old definition of shared national experience was watching TV at the same time. This shared experience is happening with TV in the background. The In- 
ternet is our connection machine and Twitter is the new Times Square. (Cited in Newman, 2011, p. 32)

According to the special report of The Economist (2011), the social and new media are taking the audience back to the conversational culture of coffeehouse. For Newman (2011) the change means 'more than that':

The new electronic coffeehouses are not replacing the mass media; rather, they live in a symbiotic relationship, feeding and amplifying each other....The news itself may emerge first via Twitter, but it is the mass media that pick it up and package it for a mass audience. (Newman, 2011, p. 56)

It is thus 'the interplay between mainstream media and social media' that makes most news organisations recognise that there is no turning back from this new 'social ecosystem', argues Newman (p. 56). As new networks such as Google+ and social aggregators like Flipboard, WhatsApp, news.me and Zite are emerging, he maintains, the news will continue to become more personalized and customized for the audiences; 'and yet none of this replaces the role of a traditional news organisation'. 'The need for quality content to be produced, packaged and distributed remains crucial for the new ecosystem to function and flourish', even though the news publishers already realise that 'there is no alternative but to engage-hard and fast' (p. 56).

\section{Broadening the Journalism Model}

The 'new distinctive forms of communication' that Matheson and Allan (2010, p. 187) have pointed out in their study hints towards the change in the traditional journalism model to include the platforms and medium offered by the social, new and alternate media. And what Newman refers to as the symbiosis between the various media platforms is clearly the phenomenon that is already taking place - the 'broadening of journalism model' in the age of new media.

Verbitsky, an academic on conflict resolution at Auckland University of Technology (AUT), used the term in an interview (January 2014) with the author during her doctoral research when she was asked to comment on the nature of relationship between conflict resolution and journalism. According to Verbitsky it is an attempt to free journalism from the demands of 'the orthodox model of objectivity' which can be 'very rigid and modest in the way it approaches war' (Aslam, 2014, pp. 149-151). To start with, Verbitsky draws the line between conflict resolution as a practice and as a means to help journalists play a positive role in reporting conflicts. In her opinion, journalists need not to become 'conflict resolution practitioners' in order to help people resolve conflicts or build peace. Rather, one needs to be careful 'in trying to delineate the parame- ters of what journalists could do,' she says. But there are other ways 'of being a journalist, of being faithful to what journalism is about, without having to take that model (of conflict resolution) on board,' she says. Journalists should be able to work within 'the new models to deliver information and possibilities about how conflicts can be resolved.' (p. 149)

This requires 'a broadening of the concept of journalism to embrace other forms and models which are much more cognizant' than the 'orthodox model' of objectivity that dominates the mainstream media. 'For me the old model is fine for the period in which it came into being, but for the $21^{\text {st }}$ century it is too simplistic, too commercial,' she says (p. 150).

Verbitsky's call to broaden journalism's model is a means to enable the journalists to ask critical questions, expose truth, find spaces and open dialogues. It is reinforced by her emphasis on what they can learn from the field of conflict resolution: conflict analysis, conflict transformation, dialogue building, and facilitation in order to bring the parties on a platform to communicate. 'In the $21^{\text {st }}$ century we have seen so many changes in so many situations, so many transmutations, that I think journalism needs to transmute to keep pace with what is happening and to reflect the reality of situations,' (p. 151). For that purpose, journalists must learn 'how to deconstruct a conflict', she points out. How to do it? She suggests going back to journalism practices:

The journalistic way of asking 5Ws [who, what, when, where, why] are a good point to start with....But then you need to add on more information about the needs and interests of the conflicting parties, as well as those of the other stake holders in the world such as the super powers, nuclear powers and the regional players. There is also the element of the historical context and exploring what avenues can be opened for a dialogue. (p. 151)

However, the difficulty for the journalists in doing so, Verbitsky concedes, is in 'trying to persuade the editors and media owners they can do it without threatening the integrity of the news that they are producing'. But the argument can be made, she points out, that the journalists' integrity lies in their ability to ask questions:

...because if they don't, how do you get a critical analysis of what is going on....So for journalists to have integrity, I think, they have to ask questions of everybody. And it's not just who is the most powerful one, it's just everybody who is connected with that conflict in order to try and get to a space where people can make their own judgments as to where the truth lies; and to open up the possibilities for a dialogue and the space for engagement in conflict resolution. (p. 150) 
One of the reasons why people get cynical about the news, Verbitsky reflects, is that 'when the orthodox model is employed, it's all gloom and doom on conflicts and no prospect of anything other than conflict continuing on indefinitely' (p. 150). But the journalists can also see conflicts in terms of 'human relationships' and help people in connecting with each other. Giving the examples of Rwanda and Nazi Germany, Verbitsky finds that's where Track II diplomacy is 'very valuable':

For people at the level of community leadership to meet their counterparts in Track II diplomacy, to exchange stories and narratives, to hear about how the conflict impact each other, to recognise each other's humanity and to see the possible spaces, even if they are small spaces, where some kind of conflict resolution can be engendered, can be important. (p. 150)

\section{The 'Objectivity Regime'}

Verbitsky is not the only one to find 'the objectivity model' lacking in terms of informing the public on peace and conflict issues. Starting with Galtung (1996), Lynch and McGoldrick (2005) and Hackett \& Zhao (1998), many academics have 'repeatedly demonstrated the shortcomings of existing journalism when measured against the stated ideal of objectivity', (Hackett, 2011, p. 39). According to Hackett, objectivity is a 'paradigm or regime, a metaphor that calls attention to the interlinkage of practices, norms, epistemology and structures in journalism' (p. 37). These practices include the notions of 'accuracy', 'fairness', 'balance', 'separating "fact" from "opinion", 'the privileging of personalities over structures, political strategies over policy analysis, and discrete and timely events over long-term processes, conditions or contexts' ( $p$. 39). To the extent that employment of such practices requires specialised skills, 'objective reporting enhances journalists' claim to professional status' (p. 38):

When measured against sensationalism or wilful propaganda, these objectivity practices have much to recommend them.... Yet they also have predictable consequences that are highly problematic for informing public opinion, or incentivising remedial action, in relation to global crises of conflict, ecology and poverty. (Hackett, 2011, p. 39)

Objectivity is considered as the fundamental tenet of contemporary reporting that refers to the factual basis of reporting. It is 'the value of fairness' and 'the ethic of restraining your own biases' says American journalist Rosen (cited in Lynch \& McGoldrick, 2005, p. 203). But Bell's (1998) experience of covering the Bosnian ethnic cleansing in 1994-95 as a BBC correspondent led him to criticise the BBC's guidelines for reporters to be objective and dispassionate. He argues:
I am no longer sure what 'objective' means: I see nothing object-like in the relationship between the reporter and the event, but rather a human and dynamic interaction between them. As for 'dispassionate', it is not only impossible but inappropriate to be thus neutralised-I would say even neutered-at the scene of an atrocity or massacre, or most man-made calamities. (Bell, 1998, p. 18)

Lynch and McGoldrick (2005) are particularly critical of the journalists' defence of objectivity. For them, journalists are involved whether they like it or not. Nor can they be wholly objective-they only see a fraction of the action especially in battle, they do not know the whole picture. For the same reason they question how the reporter can claim to be reporting the truth-a small slice of truth, perhaps, not the whole picture. And a partial reporting of the truth often distorts the overall picture.

For them, it is about making 'choices' in terms of 'what to report, and how to report' in conflict (Lynch \& McGoldrick, 2005, p. 5). These choices 'create opportunities for society at large to consider and to value non-violent responses to conflict'.

Objectivity then is not the issue: 'Selection is the issue, the criteria applied and the codes and the context in which the event is placed and interpreted' (Lynch \& Galtung, 2010, p. 52). Rosen (cited in Howard, 2003) says:

We make an error if we assume that the price of an interest in conflict resolution is giving up commitment to truth and professional objectivity. It is in fact quite the opposite: conflict sensitivity is a journalist's pass into a deeper understanding of what it means to seek the truth in journalism. (Rosen as cited in Howard, 2003)

The 'beneficiaries' of the objectivity regime, according to Hackett, are many: including the 'commercial daily press', 'news agencies', journalism's institutional status, 'politicians', and 'the interested groups that had the resources and willingness to play the game' (Hackett, 2011, p. 38; also see Hackett \& Zhao, 1998, chapter 3). But the downside is that 'objectivity regime helps to manage the symbiotic relationship between news media and the state' (p. 38) thus making the media a propaganda tool in the hands of the state (Herman \& Chomsky, 2002). The framing and agenda setting by the media, in terms of what makes the news, can determine the public opinion and also reflect journalists' personal perceptions and prejudices when they interpret the conflict for the audience (Aslam, 2010). The media-state symbiosis is also affected by the competition that exists among the news media to capture the audience and ratings (Hackett, 2007; Wolfsfeld, 1997). 


\section{What the 'New Model for Journalism' Means?}

One can evidently find considerable scholarly support on the need for a 'broader model for journalism' to improve the standards of contemporary journalism in conflict reporting and peace building. But what exactly does it means in terms of practical journalism and professional trends and values? Following is the discussion on what it implies for the journalists involved in conflict and peace reporting.

\section{1. 'Peace' as the $11^{\text {th }}$ News Value}

Conflict is a news value because it sells-Galtung and Ruge (1965) and Harcup and O'Neil (2001) tell us in their studies. While Galtung and Ruge listed the elements that make up the foreign news; Harcup and O'Neil (2001) in their follow-up study identified ten dominant elements as to what constitutes the news: power elite, celebrity, entertainment, surprise, bad news, good news events, magnitude or scope, relevance, follow-up and the newspaper own agenda.

The first implication for journalists is to make 'peace' a news value. Many scholars have argued in favour of attributing journalism with the 'value explicit approach' of peace but with the journalistic commitment to state the facts and a clear recount of how these facts are met (Galtung, 1996; Lynch, 2013; Shaw, Lynch, \& Hackett, 2011). This would lend it the legitimacy to be included within the paradigm of professional journalism. Peace is an important attribute as it brings in 'the values of transparency and responsibility', says Lynch (cited in Aslam, 2014). 'The opposite of value explicit is not value neutral but value concealed':

And if you are value explicit and you are in favour of 'peace' and you are in a privileged position...then there is an onus to follow through from theory to practice; there is an onus to involve one's self in debates generally and make a contribution to them. Not only to reflect opinion but also to lead opinion. (Interview, May 2013, cited in Aslam, 2014, p. 156)

The new paradigm of news values allows peace story or event to become the 'news' when a war becomes 'a routine, terrible but repetitive, monotonous, plainly boring..... In that case the peace event...is a farewell to boredom' (Lynch \& Galtung, 2010, p. 18). 'Both violence and peace are texts. Whether they are (newsworthy) events depends on the context.' Lynch further overarches this paradigm to apply to the overall framing of news when he talks about the value of good journalism being in its ability to 'throw up' the stories that are 'unusual to the norm' and that make the 'good bits of journalism' (Aslam, 2014, p. 160).

However, related to making 'peace' a news value is the tricky matter of defining the term 'peace' itself-an issue that leads people to confuse it with 'activism' and 'advocacy' (Kempf, 2007). Peace has always been associated with war and conflict. Barash (2000) argues that peace is never fully achieved, but can only be approached. Kempf (2003) gives various meanings of peace ranging from it being the 'absence of war' to being a 'state of harmony'. Galtung (1996) argues that peace has a 'fatal connection' with war-he terms the mere 'absence of war' or ceasefire as 'negative peace'. On the other hand, 'positive peace' is the condition in which other 'non-violent' ways are available to the society to deal with conflict. 'In positive peace, aspects of structural and cultural violence are exposed, and challenged, and this requires openness and inclusiveness in public spheres, to allow monitory democracy' (Lynch, 2013 , p. 50). If conflict is defined in terms of "human relationships'; peace is defined 'not as the absence of conflict, but as the absence of violence' (p. 50). Metaphorically, peace can be seen not merely as a stage in time or a condition; it is a dynamic and social process of constructing peace-a phenomenon that Lederach (2003) calls 'conflict transformation'.

Related to peace, are the concepts of peacebuilding and peacekeeping. Peacekeeping is defined as the maintenance of peace, especially the prevention of further fighting between hostile forces in an area' (Collins, 2003). It may require the presence of internal and external forces to monitor and execute the truce between the opposing sides - a role that has been increasingly assigned to the UN Peacekeeping forces (Mogekwu, 2011). Peacebuilding, on the other hand, is a comprehensive concept that encompasses, generates, and sustains the full array of processes, approaches, and stages needed to transform conflict toward more sustainable, peaceful relationships (Lederach, 1997). The term involves a wide range of activities that both precede and follow formal peace accords.

Galtung (1998) explains peacebuilding as the process of creating self-supporting structures that remove causes of wars and offer alternatives in war-like situations. Such mechanisms should be built into the structures of society and be present there as a reservoir for the system itself to draw upon, just as a healthy body has the ability to generate its own antibodies and does not need ad hoc administration of medicine (Galtung, 1998; Lynch \& Galtung, 2010).

Hamelink (2011, p. 11) contends that conflict are natural part of living with others and that ultimately 'history takes its bloody route' because as long as people have different values and beliefs they will always 'see things differently'. Lynch (2013) argues that this would 'invalidate peace, if peace were indeed an end state requiring everyone to agree on everything' (Lynch, 2013, p. 50). Peace is worth pursuing because 'peace allows for people to live with conflict' and in its non-violent response to conflicts, peace finds 'alternatives to "bloody routes"' (p. 50). 
Non-violence then, according to Lynch (2013), is an essential aspect of peace, a thread that he traces in the history of anti-war and peace movements against the threat of nuclear warfare, which led American President Johnson (and later his successor Richard Nixon) to turn down Pentagon's proposal to launch nuclear strikes against Vietnam in 1966. The biggest ever demonstration in New York's Central Park by the Nuclear Freeze Movement 'effectively' toned down President Reagan's rhetoric on waging nuclear attacks against the Soviet Union and he declared it 'unwinnable' (Lynch, 2013, p. 47). Some other examples of successful non-violent movements include Gandhi's nonviolent civil disobedience movement during the Indian freedom struggle (1936-1947); the US Civil rights Movements led by Martin Luther King Jr; and 'the mass movements that brought down the Communist regimes of Eastern Europe in 1989' (Lynch \& Galtung, 2010 , p. 59). A non-violent approach is then essential to the journalism that makes peace a news value.

In the respect where peace is associated with a country's interests and goals, the term peace can be 'notoriously polysemic, to the point where it can sometimes seem to mean all things to all people' (Lynch, 2013, p. 46). Chami (2010), member of Beirut-based NGO, the Forum for Development, Culture and Dialogue, records his experience in media training that involved journalists from Lebanon, Saudi Arabia, Egypt and Palestine-countries where the US-sponsored Middle East peace process has given peace a bad name (Zogby, 2003). The term 'peace' in Arabic could be translated as salam, he says, but this 'has been sensitised to give the connotation of peace with Israel which tends to be problematic to many Arabs who would shy away from, if not attack the discipline altogether without really delving into its depth' (Chami, 2010, p. 18). Instead the participants were willing to accept the translation as silim which 'portrays more a kind of civil peace-something more internal' (p. 18).

Chami's experience also provides 'an alternative understanding of peace' in its attempt 'to discern and live by peaceful values, at every level: from our own interiority' (Lynch, 2013, p. 47). It is an 'insurgent form' that is 'nurtured and developed in peace movements' and is contrary to the prevalent Western 'teleological' view of peace which is 'victory oriented' (p. 47).

Mandelzis (2007) argues that in relation to the news media, "the notion of "peace" has still not been adequately conceptualised' (p. 99). In her study of peace discourse in the Israeli news media, she found that 'studies on media peace discourse per se are extremely rare, and peace itself is not strongly emphasised in the media or elsewhere' (p. 98). She also notes the observations made by Groff and Smoker (2002) who said that although the term 'peace' has been 'increasingly popular' among the leadership of UNESCO; there is no 'clear consensus' on how to interpret it.
Mandelzis further argues that 'perhaps it is the lack of perspectives on 'peace', among other things, that also explains the scarcity of literature on the relationships among the mass media, communication and the culture of 'peace' (2007, p. 98).

Bratic and Schirch (2008), too, have argued that while there has been an 'optimistic shift' in the media's role in conflict, 'the theoretical argument for the media's impact on peace is under-developed, the practical projects are vastly scattered and a systematic analysis of the practice is missing'. Moreover, the debate reiterates the media's social responsibility model and 'its universal and philosophical nature tends to divert and dilute the discussion'.

Hawkins' (2011) maintains that it is because 'peace is a process, not an event' (p. 262) and because the 'needs of the media corporations' in going about the business of constructing news 'do not fit well' with the needs of peace related journalism (p. 263). He quotes Wolfsfeld, Alimi and Kailani (2008):

A successful peace process requires patience and the news media demand immediacy. Peace is most likely to develop within a calm environment and the media have an obsessive interest in threats and violence. Peace building is a complex process and the news media deal with simple events. (Wolfsfeld et al., 2008, cited in Hawkins, 2011, p. 263)

But this is not to assume that the peace events cannot be 'exciting' (Mandelzis, 2007) or without the promise of 'drama' (Hawkins, 2011). Events like 'the historic Oslo handshake on the White House lawn in September 1993', 'the ceremony marking the peace agreement between Israel and Jordan (27 October 1994)', and 'Elton John's concert in Belfast (May 1998) celebrating the peace agreement in Northern Ireland' can be 'fascinating ceremonies' (Mandelzis, 2007, p. 109). Whereas 'the tension of the bitter foes coming to sit at the same table, the outbreaks of residual violence that threaten to ruin the process, the threat of walkouts, the anticipation of a successful outcome' can provide the media with 'both action and drama' (Hawkins, 2011, p. 264).

\section{2. 'Connecting with People' and Knowing 'How to Do It'}

Mohammad Wajih, a peace worker who works with people in peace and conflict situations in Pakistan, says that journalists can build peace in societies in the digital age by doing two things: 'connecting with people' and 'choosing the right medium'. Wajih was also interviewed by the author during her visit to Pakistan in April 2012 for her doctoral research (Aslam, 2014, pp. 144-147). As the former programme director for Search for Commonground in Islamabad, the US-based NGO that funds projects in peace building and Track II di- 
plomacy, he has extensive experience in helping the communities bridge the conflicting issues at social level (www.sfcg.org). Currently he is the Director Programmes, Intermedia, Pakistan, a non-profit organisation that works on bridging the communication gap between people through media.

For Wajih, it is important for the journalists to connect with the people who are affected by the conflict rather than tag along the official sources. Focusing on the similarities between the different sides is even better, especially if it is an old conflict. He supports his argument by giving an example from his experience in dealing with the Nepal-Sri Lanka and Pakistan-India conflicts.

'One of the main areas of common grounds between nations is sports, so we built on football during the Nepal-Sri Lanka conflict and cricket for PakistanIndia conflict. This way we tried to create a positive channel for the youthful energies,' Wajih explains. They produced a 26-episode radio drama called 'The Team' in 2011 for the audience in Pakistan, Kashmir and India. It was a series of stories about a group of cricket players who came from different regions with different social, cultural or political backgrounds in a team but each story also highlighted the common issues and situations that faced them as human beings while they interacted with each other. In the end, the players were able to reconcile their differences and develop positive relationships among themselves (p. 144).

'The project was a great success', Wajih recalls. One of the reasons, why it was so readily accepted by the audience was probably the fact that the project did not use professional actors. 'We went on a talent hunt from within the communities to find young men and women for playacting and they connected with the audience immediately as real people facing real issues that were similar to their own' (p. 145).

Wajih's belief in the media's ability to leave a positive impact when it is 'connected' with people and communities is supplemented by another equally strong belief: the importance of choosing 'the right kind of media' to relay such messages. 'When you are working with the communities, it is important to engage with them in the language they understand and the medium that is part of their daily lives' (p. 145).

Therefore local and regional language-based community radio or TV channel can become an effective means of promoting messages among the rural communities helping them change attitudes, accept peace building initiatives and ultimately helping to resolve conflicts, he says. In the bigger cities with a more literate audience, it would be the newspapers, magazines and national TV channels and at the international level, the social media can be effective. But when civil infrastructure is in shambles during active armed conflict, stories have come out of small communities through the social, new and alternate media.

Journalists, in Wajih's opinion, therefore can play an important in role in reducing violence and building peace if they know 'how' to do it.

If journalists are not trained professionally; if they do not know how to engage the conflicting parties in a dialogue without losing the control of the conversation (e.g., in a talk show); and if they do not know how to connect with people, they will only enhance the conflict without even knowing it. (p. 146)

However, Wajih cautions against another problem and that is when all kinds of journalists get involved in reporting and analysing a conflict. 'This brings forth a plethora of assumptions, presumptions and biases which makes conflict resolution even more complicated because then people do not know what and who to believe,' he says.

At the basic level, all journalists need to know how to analyse conflicts and how to communicate with people. But they also need to identify their own role as to 'how' they do it? Newspaper commentators and analysts, TV anchors, talk-show hosts, programme mediators, even entertainers, all have roles in the media that is very different from the role of the journalists who work and report in the conflict zones. The important thing is to know the best and most effective way to give the message of peace within their areas of expertise (p. 146)

Equally important is for the journalists to be "honest and forthright in what they say and why they say it', continues Wajih, 'it is a matter of personal ethics and integrity.' It is commonly thought that the big names in journalism always say the right thing; not necessarily so. 'In my experience big-time old-hand journalists are equally-if not more than their younger colleaguessusceptible to taking positions on an issue out of ignorance or arrogance,' he argues. 'Also, because they are famous they are specifically targeted by the parties who have stakes in the conflict and can fall prey to coercion or corruption.'

Wajih recalled when in 1984 India carried out nuclear missile tests and there was international diplomatic pressure on Pakistan not to retaliate in a similar manner, the Pakistani media was urging the government to do otherwise. When Pakistan carried out its own nuclear tests, many countries enforced sanctions against Pakistan. 'How was that a peaceful suggestion (made by the Pakistan media) for the country? Or even helpful for the people who for the many next years had to face severe economic and social problems,' he asks.

\subsection{Blurred Lines}

The massive shift in the new age media platforms has not only impacted the nature of the audiences, it has 
also affected the scope of journalism as a profession. Lynch points out in an interview with the author in May 2013, that 'the lines are blurred' not only between the mainstream media and social media but also between the journalism careers (Aslam, 2014, pp. 153-157). 'Journalistic careers are in many cases a lot less linear', he says. For instance Lebanese journalist Vanessa Basil, who attended Lynch's workshop on peace journalism in Lebanon and went to practice it in all kinds of media. In his opinion, she is a very good example of how she has made use of social media, intended outcome, donor media, commercial media, Arab media, western media, and international media and creating opportunities for herself through it. Basil is active in social media. 'She is doing "gigs" in all kinds of media and she has built her own identity through using social media' (p. 156).

As the lines between the mainstream traditional media and social media are getting blurred, other scholars and journalists have also welcomed the 'freedom' and 'flexibility' that it can offer to journalists who engage in peace building (Hawkins, 2011; Mogekwu, 2011). They can make use of this 'cross-over role' and join forces with social media and other civic movements like communication rights if their efforts are calibrated with due sensitivity to context' (Hackett, 2011 , p. 47). But in order to do so, they must develop, between them strategic approaches capable of motivating exponents in both fields. This flexibility also offers journalists the creativity to shape meaningful messages in a format that is not confined to news media but appeals to the masses in other media forms such as photojournalism, documentaries and entertainment.

Suchenwirth and Keeble (2011), also the proponents of using social media for peacebuilding, enlist the peacebuilding initiatives across the world where social media has played a positive role in gathering and disseminating the information. They assert that the community media is 'the most promising milieu for peace journalism' as it actively promotes human rights and social change (2011, p. 12).

Alia (2010) voices similar thoughts in her study Crossing Borders: The Global Influence of Indigenous Media, where she says that during the 1990 confrontation between the townspeople at Oka, Quebec, and the people of the Kanehsatake Mohawk First Nation, 'radio played a crucial role in providing public information, conflict prevention and conflict resolution' ( $p$. 128).

\subsection{Broader 'Claim of Humanity'}

Journalists are often referred to as the fourth estate and the guardians of public trust. Indeed Siebert, Peterson and Schramm (1963) have argued that journalists have a social responsibility to criticise those in power on behalf of the peoples and societies, more or less serving as their watchdogs (Curran, 2011; Siebert et al., 1963).
The Article 3 of the 1978 UNESCO Declaration states that 'the mass media have an important contribution to make to the strengthening of peace and international understanding and in countering racialism, apartheid and incitement to war' (UNESCO, 1978, p. 1). The social responsibility of journalism, in Nordenstreng's opinion, calls for initiatives 'to systematically monitor what the media tell about the world with a view to improving media performance and contributing to media ethics' (2001, p. 1).

Moral responsibility to society, it thus follows, is an important obligation of journalists. Shaw (2011) has argued in favour of linking journalism with a more 'proactive (preventive)' role of media in conflict rather than a 'reactive (prescriptive)' role:

If journalism is to play any agency role in conflict, it should focus on deconstructing the underlying structural causes of political violence such as poverty, famine, exclusion of minorities, youth marginalization, human trafficking...rather than focusing merely on the attitudes and behaviours of the elite that benefit from direct and uncensored violence. (Shaw, 2011, p. 108)

Such an approach that entails a more 'avowedly proactive' role for peace journalism must aim for greater public interest (Lynch, Hackett, \& Shaw, 2011, p. 12). A relevant question at this point would be: since the peace journalism's philosophy is rooted in the social responsibility theory (Kempf, 2007, p. 3; Lynch \& McGoldrick, 2005, p. 4) what are the implications of this approach on the journalists' obligations to the society in a global age, where conflicts transcend geographical boundaries and encompass a global audience?

In his epilogue to The Invention of Journalism Ethics, Ward (2005) argues that it broadens the 'claim of humanity' on journalism:

If contemporary journalism is to seek to represent the truth, there must be a re-conception of the journalism's social contract and its public.... The new social contract requires that we add what I would call the 'claim of humanity' to the principles of journalism. The claim states that journalists' primary allegiance is to truthful, independent informing of a global public humanity. When considering one's journalistic duty, a reader's place of birth, residence, race or cultural group is morally irrelevant. (Ward, 2005, p. 328)

Ward's claim of humanity hints at the shift in the way journalists' role in society can be looked at in the age of new media. Modern journalism in 21st century, in Bacon's words, needs to be 'both local and global'. In fact the 'failure of the mainstream media to achieve this is one aspect of the crisis in journalism' today (Bacon, 
2011, p. 53). She calls on the universities to embrace this aspect again by accepting the investigative journalism as research methodology in academics and collaborating with other universities to give space to the students' investigative journalism.

\section{New Journalism Models}

Castells (2007) has argued that the increased usage of the alternate media through the internet in the twenty-first century demonstrates a "historic shift of the public sphere from the institutional realm to [a] new communication space'-one in which 'insurgent politics and social movements can intervene more decisively' (p. 238). In fact, he asserts that 'the media have become the social space where power is decided' ( $p$. 238). Such media centric stance warrants 'further scrutiny of the power relations at work within media domains' (Lynch et al., 2011, p. 8). Hence there have been efforts by the journalists and academics including Bell (1998), Galtung, (1965, 1969, 1996, 2010), Lynch and McGoldrick (2005), Shaw (2011), Lynch (2010, 2013), Tehranian (2002, 2007), Shinar (2007), Keeble, Tulloch and Zollmann (2010), and Hackett $(2007,2011)$ to find alternate ways to help journalists engage in the 'journalism of attachment', one that 'cares as well as knows' (Bell, 1998, p. 16); that is 'responsible' and 'accountable' (Howard, 2003) in reporting conflicts. Such journalism would not contribute to escalating conflict situations but would find 'non-violent' responses to them (Galtung, 1996); such journalism would also be 'ethical' and professionally ascribe to the standards of 'good' journalism (Lynch, 2013).

A host of new concepts have come forth starting from 'the journalism of attachment' (Bell, 1998) to include the notions of 'citizen journalism' (Allan, 2007), 'reliable journalism' (Howard, 2003), 'development journalism' (Dixit, 2010), 'critically deliberative journalism' (Robie, 2013), 'conflict sensitive journalism' (Howard, 2003) and 'peace journalism' (Galtung \& Ruge, 1965). All of them are essentially drawn from the notions which stress the social responsibility of the media and advocate a proactive role for the media in resolving conflicts and aim towards peace. There were other titles too, as mentioned by Shinar (2007, p. 205) that include 'victim journalism' (Hume, 1997); 'justice journalism' (Messman, 2001) and 'engaging' journalism (Lynch, 2003).

Yet it is peace journalism that has been the focus of the debate and whose theoretical and conceptual framework has been significantly developed in the past two decades. It is partly because the term 'peace' is provocative in both ways, eliciting a negative and positive response from people (McGoldrick, 2007). And partly because many scholars do not see peace journalism deviating from good journalism practices. For instance, Robie (2010) argues that much of peace journalism is the combination of an individual's approach to a conflict situation and plain good contextual journalism. Ross (2007, p. 74) maintains that 'peace journalism does not involve any radical departure from contemporary journalism practice'.

Peace journalism is therefore discussed here as one of the alternate and broader models for journalism in the new age that can help maximise the role of journalists in peace building and conflict reduction. The other three are the alternate journalism and communication rights movement as proposed by Hackett (2011) and human rights journalism by Shaw (2011). They are then discussed in the light of each other along with their implications for journalism as a profession.

\subsection{Peace Journalism}

Galtung and Ruge (1965) in their examination of the structure of what makes the foreign news have presented the peace journalism model as an alternative to the prevalent model of war journalism that is based on the 'objectivity regime'. Peace journalism has its orientation towards peace process as opposed to violent events; truth as opposed to propaganda; people as opposed to the elite and solution as opposed to victory. It is seen as an 'insurgent form' of the traditional norms and practices of the media coverage of conflict (Lynch, 2013). Peace journalism is defined as 'a set of tools, both conceptual and practical intended to equip journalists to offer a better public service' (Lynch \& McGoldrick, 2005, p. 5). It is a form of journalism that tells stories 'in a way that encourages conflict analysis and a non-violent response in society' (Mogekwu, 2011, p. 247). It not only helps to reduce conflict, it acts as a means for peacebuilding (Hawkins, 2011).

Peace journalism, it follows, is seen by its advocates as a 'deliberate creative strategy conceived as a specific response' (Lynch, 2013, p. 36) to Galtung and Ruge's (1965) study of the 12 factors 'which make an event a worthy candidate to become news' (Lynch \& Galtung, 2010, p. ix). Its 'value-explicit approach' (Lynch et al., 2011 , p. 9) with the journalistic commitment to remit the facts and a clear recount of how these facts are met, lends it the legitimacy to be included within the paradigm of professional journalism (Lynch, 2013).

Peace or conflict reporting then becomes an opportunity for 'not only reporting the truth but the whole truth' (Lynch \& Galtung, 2010, p. 2). Truth, which can be gleaned through the journalistic 'supply of cues and clues, to alert readers and audiences' to the propaganda trappings of the conflicting sides (Lynch, 2013, p. 38). It also gives a choice to the editors and reporters of what to report and how to report which in turn creates opportunities for the audiences to find non-violent responses in society (Lynch \& McGoldrick, 2005, p. 5). 'Peace journalism is a serious, inquisitive, professional reporting making conflict more transparent' (Lynch \& Galtung, 2010, p. 17). 
If the above arguments are taken into account, then peace journalism can legitimately present itself as a more complete and accurate form of journalism than the standardised and stunted practices of objectivity, observes Hackett (2011, pp. 47-61), in his examination of peace journalism as an alternate paradigm for journalists. Within the ideological framework presented by its advocates, it claims a 'toehold in the established media field' by embracing the 'the best ideals of journalistic profession-including comprehensiveness, context, accuracy, and the representation of the full range of relevant opinions... while providing practical alternatives' (p. 41). Yet it also challenges the epistemology of the objectivity regime as well as the dominant news values. For instance, journalists in conflict situations are caught up in the feedback loop with the political players who with their spinning of facts, half-lies, secrecy, propaganda and embedded journalism tactics can make journalists unwittingly play a part in escalating conflict. 'Objective journalism can thus be "irresponsible" in that it shuns Max Weber's ethic of responsibility in public affairs'-a notion that goes against the journalists' own moral responsibility to society (p. 42). 'PJ thus challenges the very epistemological basis for a stance of detachment, calling instead for journalists to be self-reflexive vis-à-vis the institutional biases of their routine practices' (p. 42).

At the same time, peace journalism challenges the dominant news values that implicitly provide a criteria and 'routinely guide journalists in selecting and constructing news narrative' (Hackett, 2011, p. 43). Harcup \& O'Neil (2001) in their follow-up study identified ten dominant elements as to what constitutes news: power elite, celebrity, entertainment, surprise, bad news, good news events, magnitude or scope, relevance, follow-up and the newspaper own agenda.

Hackett's final argument in favour of peace journalism is that it implies 'not just the right to speak freely, but also a right of access by all significant voices to the means of public communication' (p. 44). Keeble (2010, p. 64) too has favoured this argument: that there is 'the need to acknowledge the right of all (and not just the members of the professionalized, privileged and largely white, male elite) to communicate in the main or alternative public spheres'. He strongly advocates that peace journalism be taken away from the mainstream media and made a 'political practice' across the internetbased media. His reasons are based on Falk's argument that 'if peace journalism is to become more than an argument at the outer margins of political debate; it has to become a political project on the agenda of global reform' (Falk, 2008, as cited in Keeble, 2010, p. 64).

\subsection{Alternate Media, Communication Rights Movement \& Human Rights Journalism}

Hackett (2011) further examines peace journalism against what he calls two other 'challenger paradigms'-alternate media and communication rightsthat challenge aspects of media structures and practices. Alternate media is the term used as opposed to the structure and message of the news disseminated by the mainstream media and is also described through adjectives such as alternative, alterative, radical, autonomous, independent, tactical, citizens', participatory and community media (Kidd \& Rodriguez, 2010, p. 1; also see Hackett, 2011, p. 46).

An ideal type of alternative journalism, as defined by Hackett (2011), is 'participatory' in production of news; challenging 'established media power'; rejecting 'conventional elite-oriented and conservative news values'; taking a more 'bottom-up ways of scanning and reporting the world'; and demonstrating 'a positive orientation to social change, social movements and/or marginalised communities' (p. 47). Drawing his arguments from Atton (2009), Atton and Hamilton (2008), Brooten (2008), and Hackett and Zhao (1998), Hackett argues that 'alternative journalism is complementary to PJ in several ways' (p. 47). It represents 'dissatisfaction not only with the mainstream practices and coverage, but also with the epistemology of news' (Atton \& Hamilton, 2008, p. 1, cited in Hackett, 2011, p. 47). Conversely, it seeks to represent 'the under and mis-representation of subordinate groups' and 'marginalised communities'; it also favours 'social change and social movements' by embracing the concept of 'learning by doing'-i.e. people's participation and experience (Hackett, 2011, p. 47). Hence, it constructs 'a reality that opposes the conventions and representations of mainstream media' (Atton, 2008; Brooten 2008, cited in Hackett, 2011, p. 47). Moreover, alternative journalism also shares with peace journalism 'a commitment to move beyond the reporting of daily events, to analyse contexts and to critically explore the structures of power' (p. 48).

To be sure, there are some tensions between the two kinds of journalism (Hackett, 2011, p. 50-51) such as the 'presence and desirability of professional' in peace journalism as opposed to 'people telling their own stories' in the alternative media; or the alternative media advocating 'for one side of a conflict' may oppose to peace journalism precept of 'productive dialogue between the different parties in a conflict'. But, Hackett's emphasis is more on the 'profound complementarities' between the two (p. 51) that can be profitable to both sides.

Both paradigms reject the epistemology of the regime of objectivity, insisting that journalists acknowledge they are embedded in social processes and communities, and act ethically on that basis. Both seek to challenge elite war propaganda, and to broaden the range of voices accessed to the public arena, especially those of peacebuilders and the victims of violence in conflict situations. (Hackett, 2011, p. 51) 
The second challenger paradigm is based on the civic society advocacy movements such as the media justice, media reform and international civic society movement for communication rights (CRIS) working together on the common principles of 'freedom', 'equality', 'diversity and pluralism', 'participation', 'responsibility', 'human rights', 'communication rights' and 'knowledge as common good' to form 'a coherent paradigm of democratic communication' (p. 58).

'The overarching paradigm, arguably, is the institutional organisation so as to enable all segments of society to participate in constructing public cultural truth,' argues Hackett (p. 59). This paradigm brings about the 'democratision' of media 'through the media' and pegs on the ethics of 'listening to and taking into account, the needs of the other, as a nucleus for both democratic communication and social justice' (p. 59).

In the light of this description, Hackett argues that 'alternate journalism is complementary to PJ [peace journalism] in several ways' (p. 46). According to him then, 'peace journalism and media reform/communication rights could similarly envisage strategic alignment and common principles' to develop 'new strategies' through the alternate media. He argues:

Structural reforms applicable to all three challenger paradigms include public and community media that offset the biases of corporate media towards commercial and political propaganda; subsidies for media production and access in the global south; genuinely internationalist media; affordable and equitable access to networked digital media; and governance regimes that reinforce popular communication rights. In the final analysis, all three challenger paradigms point beyond the objectivity regime, towards an ethos of dialogue and an epistemology of selfreflexivity, and to fundamental change in media and social structures. (Hackett, 2011, p. 63)

Another model that broadens the traditional journalism model is given by Shaw (2011) who extends the dimensions of peace journalism to include human rights by arguing that the two strands complement each other in fighting the plight of mainstream journalism. Human Rights journalism 'has the potential to complement peace journalism's contribution to global, long-term, proactive, and sustainable justpeacebuilding' (Shaw, 2011, p. 108). The model is drawn on Schirch's justpeace framework (2002) and Galtung's positive peace framework (1996). Galtung's model of positive peace framework suggests that the roots of violence and conflict are rooted in the structural and cultural foundations of society. Any peacebuilding effort without consideration of rights of the people would render peace as sterile and negative (1996). Schirch has argued that the concept of justpeace is a hybrid of human rights and peace as it builds on 'a restorative vi- sion of justice, aimed at meeting basic human needs of both victims and offenders while holding the latter accountable for their crimes' (Schirch, 2002, p. 212, cited in Shaw, 2011, p. 101). 'The field of human rights fits into a long term plan for building justpeace', argues Schirch, "by contributing analytical tools, value frameworks, and by playing a variety of roles in peacebuilding practice.' Hence there are no contradictions between human rights and peacebuilding goals within the justpeace framework (Shaw, 2011, p. 101).

Shaw further builds his arguments on the works of Ife (2007), Larssen (2009), the war ethics of Frank (2007), Walzer's just war theory (1992), and philosophical deliberations of Kant (1963/1784; see Shaw, 2011, pp. 101-103).

Shaw argues that both peace journalism and justpeace 'have elements of critical conflict analysis and creativity' that favours dialogue and resolution. While the traditional media approach to conflict reporting is win-lose for the two parties, peace journalism's approach is 'win-win logic of finding solutions' for both sides. Here he draws from Ury (2001, p. 38, cited in Shaw, 2011, p. 105) who conceptualises justpeace as having a 'third side' that is 'a kind of social immune system that prevents the spread of the virus of violence.' This 'third side' is made up of people from the community who use the power of peers, to provide perspective of common ground, support the process of dialogue and aim for the good of the community (Ury, 2001). The point where justpeace goes further in the solutionoriented approach is where its own targeted end product is a 'triple win, a solution that meets the needs of the two parties in the conflict and the community as the "third side"' (Shaw, 2011, p. 107, emphasis added).

Evidently, the Human Rights journalism model is built on the argument that if journalism is to play any agency role in society it should focus 'on deconstructing the underlying structural causes of political violence' that manifest in physical violence. In other words, 'it calls for a robust, proactive (preventive), rather than dramatic, reactive (prescriptive) role for media in conflict' (p. 108).

Verbitsky supports the peace journalism model because it can provide the kind of space and flexibility needed to start dialogue between the conflicting parties by virtue of it being able to 'connect with people' and employ 'journalistic creativity'. 'The difference is that the journalists initiate or facilitate mediation and negotiation processes within the media sphere for the good of the people and society at large and not on behalf of any particular side', she says (Aslam, 2014, p. 153). Peace journalism can thus provide a more natural fit for the $21^{\text {st }}$ century by giving journalists the flexibility 'to try and get to a space where people can make their own judgments as to where the truth lies; and to open up the possibilities for a dialogue and the space for engagement in conflict resolution.' Verbitsky's line 
of argument also supports Newman's call for allowing journalism to form a meaningful relationship with the existing symbiosis of the mainstream with the new and social media networks (discussed above).

\subsection{The Model of the Inverted Trident}

If one is to make an argument in favour of peace journalism as an acceptable 'broader model for journalism' for peace building in the age of new media, then two final arguments in this discussion must be made. First, if the boundaries of values and ethics of journalism are to be stretched: what is the end objective? That is to say that if the traditional journalism model allows one to report 'objectively' and 'factually', what does peace journalism aim at: diffusion of conflict, resolution of conflict, peacebuilding or conflict prevention? Should peace journalism be employed after the conflict? Or should it exist beforehand, so as not to allow the conflict to happen? Literature shows the opinions are wide and varied especially given the fact how subjective the meaning of 'peace' could be in different cultures and societies as discussed above.

Lynch (2013) believes that 'peace journalism is good journalism' because its main purpose is 'to give peace a chance' (Aslam, 2014, p. 156). Mogekwu (2011) says peace journalism is better than good journalism: it is determined journalism. He also says that peace journalism should be able to prevent the conflicts in society through monitoring and detecting the early signs of discord in society. Hawkins (2011) argues that peace journalism should aim towards peacebuilding thus expanding the peace journalism movement to include not only the coverage of conflicts but also peace processes.

Hackett (2007) argues that the 'trust-bonus' that people lend to the media should be capitalised by peace journalists. Shaw (2011, p. 116) extends the dimensions of peace journalism by including human rights in it and suggesting that human rights journalism be made 'a complimentary strand of peace journalism'; McGoldrick (2011) links the new scientific discovery of human capacity for 'empathy' with peace journalists arguing how they can produce a more realistic and authentic representation of human relationships in conflicts. Tivona (2011) has brought the gender aspect to the debate and makes a call to expand the scope of peace journalism to incorporate coverage of largely invisible peace building efforts of women in conflicts.

The broad spectrum of the way peace journalism is being approached and debated in terms of what it is and what it should achieve in conflict situations can cause confusion for layman's understanding. And indeed it happened many a time when this study was presented before the students, journalists and academics at different forums and in different institutions. The audience's main concern was always: what exactly peace journalism is supposed to do and how is it practised? In the author's view, all critical approaches are important in the conceptualisation of peace journalism as a field of study. What is needed is a model that consolidates all these approaches. This can be achieved with what she has called the model of the inverted trident.

The word 'trident' comes from the French word trident, which in turn comes from the Latin word tridens or tridentis: tri 'three' and dentes 'teeth'. It is also related to Sanskrit tri ('three') and danta 'tooth'), although several Indian languages prefer another similar word, trishula (three-thorn), derived from Sanskrit, meaning 'triple spears' (Roland, 1994). In Greek mythology, trident is a three-pronged spear of the sea-god Poseidon and is the symbol of his mighty power. It is also associated with the gods Neptune and Shiva in the Roman and Hindu mythologies respectively. Commonly it is associated with being a weapon in combat and war. When inverted, it is used as a tool to catch fish and prepare ground in agriculture (Roland, 1994).

The visual presentation of the inverted trident of peace journalism is given in Figure 1.

The term is chosen because the values deemed useful for peace journalism, in the light of the above argument, come from the three strands of the media, conflict resolution practice and peace research. Some of these are the values of public trust bonus, creativity, scientific enquiry and analysis, effective communication, facilitation and initiation of dialogue by employing negotiation and mediation skills, respect for human rights, empathy and compassion for each other which can lead to the diffusion of conflict, its transformation and peacebuilding. Peace journalism can thus be defined as a form of journalism that takes its impetus from the values offered by the three strands of media, conflict resolution and peace research. Empowered by the shared values between journalists, researchers and peace workers and built on the foundations of methodical analysis, skills and strategy, the three strands converge together with the primary objective of deescalating an armed conflict. Together in a cohesive and synergised strategy, they then develop into peacebuilding and prevention of further conflict utilising the tools of researchers' enquiry and analysis to deconstruct conflict; journalistic skills and creativity to inform and educate; and strategic employment of on-ground peace initiatives that embody the values of compassion, empathy, human rights and social justice. This is the inverted trident of peace journalism, a metaphor that sees the weapon of war turn into a tool for peace. It implies that peace journalism is not a random or oneoff journalistic investigation or intervention into conflict situations, but a process that can help journalists to connect with people in a manner that is both professional and socially responsible. It is an opportunity for them to enhance their role as information providers into something more constructive and meaningful. 


\section{The inverted trident of peace journalism}

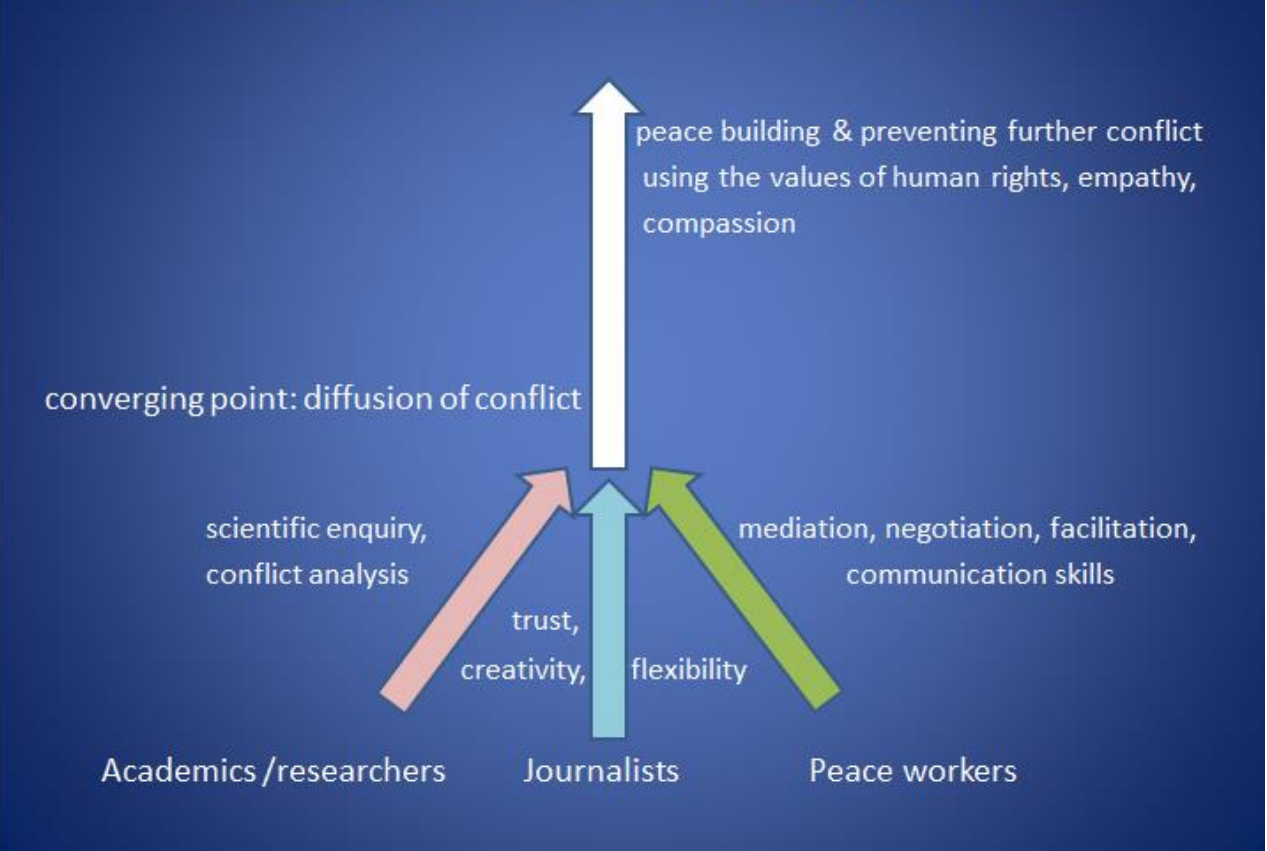

Figure 1. The inverted trident of peace journalism model that shows the values shared between journalists, researchers and peace workers. Meeting together to reduce the conflict they then unify and develop to build peace and prevent further conflict (Source: Aslam, 2014, p. 183).

This model also has the capacity to absorb the various critical approaches of peace journalism, and to consolidate them into an image that can help in the conceptual understanding of peace journalism.

\subsection{The 4P Model for Peace Journalism}

The author's second argument in this context is that the new paradigm for peace journalism would arguably also affect the political economy of peace journalism. According to Knightley (2000) the political economy of the mainstream media thrives on the interplay of 3Pspower, politics and profit. Rai (2010) argues that the political economy of peace journalism must go beyond these to include 'the kind of committed political base that was once enjoyed by Peace News in its early years' (2010, p. 209). [Peace News was North London's smalltime publication established in the 1930s on the principles of 'non-violence' and 'just peace']. Rai asserts that for peace journalists working outside the mainstream media, such support is 'crucial for economic survival and political effectiveness' (p. 209). Peace donors could be another source to lend that kind of support to peace journalism since more and more journalism is funded through extra-commercial means (Lynch, Interview May 2013, cited in Aslam, 2014, p. 157). Lynch found it 'useful' in finding the funds for his projects when they were pegged on peace. He also said that a similar argument could be made to convince the donors to sponsor 'actual slots' (paid jobs) in the media.
If the organisations working on peace can be convinced to fund peace journalism projects or sponsor job slots-in alternate media as well as in the mainstream media-then it could be argued that peace donors can become the fourth ' $P$ ' in the existing 3P model stretching the three axes of the triangle into a quadrilateral. Not a square, a parallelogram, a diamond or a rhombus but a quadrilateral, the angles of which could be drawn according to the aims, objectives and vision of that particular media that would allow it the flexibility in compromising the existing 3P-axes (powerpolitics; power-profit or profit-politics). In the author's opinion, this flexibility is crucial for any media platform-mainstream, social or alternate-where peace journalism is being practised. Especially since peace journalism is still evolving and much needs to be determined regarding its effectiveness; more so if it is to become a natural fit for the $21^{\text {st }}$ century. Although the scope of this paper does not allow a complete discussion on this model, the author nevertheless notes the need for revisiting the old model.

\section{Conclusion}

To conclude the discussion, in order for the new paradigm for journalism to play a positive role in peacebuilding calls for change in many aspects: change in the definition of who practices such kind of journalism (Keeble); change in journalism practices that are more cognizant with the principles of conflict resolution and 
transformation (Verbitsky); change in the journalists' ethics towards a wider global audience (Ward); change in finding common allies and developing synergized strategies in a more diverse media (Hackett); change in the news value system that determines what makes the news (Lynch \& Galtung); and change in possible revenue sources to sustain peace journalism and journalists (Lynch).

All these aspects are so diverse and complex that there can be no single paradigm for journalism for all times. Rather they require frequent reflection and debate. As the human society changes with time and technology, it will bring forth new contexts, new framing, new values for the news and thus room for more shifts in the existing paradigms. As van Dijck and Poell (2013) have argued 'social media networks can neither take credit nor blame for single-handedly transforming social processes or for turning around events' (p. 11). They may be seen 'as new unruly forces in a global transformation' yet they must be faced not only by the mass media but also by other institutions. The future growth of journalism-social/alternate media symbiosis will take its own course. Just as human society has been in flux from the beginning, so has journalism been dynamic, whimsical and at times idiosyncratic-and therein lies the beauty of its own symbiosis with the human society. It is therefore even more important that peace journalism retains its 'creativity' factor which will allow it to be flexible enough to survive and thrive in the future.

Moreover, while the social or alternate media can provide effective platforms for peace journalism, a synergised media strategy must exist between the journalists, academics, peace workers and researchers to utilise the mainstream media space by employing the journalistic creativity that peace journalism offers. As has been pointed out in the discussion, the lines between the various media and journalism are getting more and more blurred, and all media platforms should be explored including the news media, the entertainment media and advertising. This needs the joining of hands by the journalists, non-news media professionals, academics, peace workers and researchers to work within their own domains and come up with creative ways to give voice to the voiceless and effectively disseminate the messages supporting peace and non-violence.

\section{Acknowledgements}

Many thanks to Jane Verbitsky of Auckland University of Technology, New Zealand; Mohammad Wajih, Director Programmes, Intermedia, Pakistan; Annabel McGoldrick and Jake Lynch, Director of Centre for Peace and Conflict Studies, University of Sydney, Australia, for being so open in sharing their views and experiences with me. Gratitude is expressed to Pacific Media Centre and its Director, Professor David Robie, for his continuous support.

\section{Conflict of Interest}

The author declares no conflict of interest.

\section{References}

Alia, V. (2010). Crossing borders: The global influence of indigenous media. In R. L. Keeble, J. Tulloch, \& F. Zollmann (Eds.), Peace journalism, war and conflict resolution (pp. 121-138). UK: Peter Lang.

Allan, S. (2007). Citizen journalism and the rise of "massself communication": Reporting the London bombings. Global Media Journal, 1(1). Retrieved from http://stc.uws.edu.au/gmjau/iss1_2007/pdf/hc_final _Stuart\%20Allan.pdf

Aslam, R. (2010). Perspectives on conflict resolution and journalistic training. In R. L. Keeble, J. Tulloch, \& F. Zollmann (Eds.), Peace Journalism, war and conflict resolution (pp. 335-352). UK: Peter Lang.

Aslam, R. (2014). The role of media in conflict: Integrating peace journalism in the journalism curriculum (Doctoral dissertation). Retrieved from http://aut. researchgateway.ac.nz/handle/10292/7908

Atton, C. (2008). Citizen journalism. In W. Donsbach (Ed.), The international encyclopedia of communication. Malden, MA: Blackwell Publishing. Retrieved from www.communicationencyclopedia.com

Atton, C. (2009). Alternative and citizen journalism. In K. Wahl-Jorgensen \& T. Hanitzsch (Eds.), The handbook of journalism studies (pp. 265-78). New York Routledge.

Atton, C., \& Hamilton, J. F. (2008). Alternative journalism: Key texts. Los Angeles: Sage Publications.

Bacon, W. (2011). Investigative journalism in the academy-Possibilities for story telling across time and space. Pacific Journalism Review, 17(1), 45-66.

Barash, D. P. (2000). Preventing war: Building negative peace. In P. Barash (Ed.), Approaches to peace: A reader in peace studies (pp. 61-64). Oxford: Oxford University Press.

Bell, M. (1998). The journalism of attachment. In K. Matthew (Ed.), Media ethics (pp. 15-22). London: Routledge.

Bratic, V., \& Schirch, L. (2008). The role of media in peace building: Theory and practice. Paper presented at Journalistic Training in Conflict Relation Situations Symposium, DW-AKADEMIE, Bonn, 3 June 2008. Retrieved from http://www.kubatana.net/docs/media/ dw_journalistsic_training_symposium_2008.pdf

Brooten, L. (2008). Grassroots media. In W. Donsbach (Ed.), The international encyclopedia of communication. Malden, MA: Blackwell Publishing. Retrieved from www.communicationencyclopedia.com

Castells, M. (2007). Communication power and counter- 
power in the network society. International Journal of Communication, 1, 238-266.

Chami, J. P. (2010). Peace journalism in the Arab world: Sharing experiences and steps for the future. Paper presented to International Peace Research Association conference, Sydney, 6-10 July 2010.

Collins (2003). English Dictionary. UK: Harper-Collins Publishers.

Curran, J. (2011). Media and democracy. London: Routledge.

Dixit, K. (2010). Dateline earth: Journalism as if the planet mattered. Bangkok: IPS Asia-Pacific Centre.

Frank, T. (2007). Idealist and realist aspirations for just peace: An analysis of ethics of military force and the discursive construction of an ethic of international policing within the framework of just peace and the contemporary hegemony of international law (Unpublished PhD Dissertation). Theological Faculty, University of Aarhus.

Galtung, J., \& Ruge, M. H. (1965). The structure of foreign news: The presentation of Congo, Cuba and $\mathrm{Cy}$ prus crises in four Norwegian newspapers. Journal of Peace Research, 2(1), 64-90.

Galtung, J. (1969). Violence, peace, and peace research. Journal of Peace Research, 6(3), 167-191.

Galtung, J. (1996). Peace by peaceful means: Peace and conflict, development and civilization. London, UK: Sage Publications.

Galtung, J. (1998). High road, low road-Charting the road for peace journalism. Track Two, 7(4). Retrieved from http://ccrweb.ccr.uct.ac.za/archive/two/7_4/p 07_highroad_lowroad.html

Galtung, J. (2010). Peace studies and conflict resolution: The need for transdisciplinarity. Transcultural Psychiatry, 47(1), 20-32.

Groff, L., \& Smoker, P. (2002). Creating global-local cultures of peace. Global Options. Retrieved from http://www.gmu.edu/academic/pcs/smoker.htm

Hackett, R. A. (2007). Is peace journalism possible? Three frameworks for assessing structure and agency in news media. In D. Shinar \& W. Kempf (Eds.), Peace journalism: The state of the art (pp. 75-94). Berlin: Regener.

Hackett, R. A. (2011). New vistas for peace journalism: Alternative media and communication rights. In I. S. Shaw, J. Lynch, \& R. A. Hackett (Eds.), Expanding peace journalism: Comparative and critical approaches (pp. 35-69). Sydney: Sydney University Press.

Hackett, R. A., \& Zhao, Y. (1998). Sustaining democracy-Journalism and the politics of objectivity. Toronto: Garamond press.

Hamelink, C. (2011). Media and conflict: Escalating evil (media and power). Boulder, CO: Paradigm Publishers.

Harcup, T., \& O'Neil, D. (2001). What is news? Galtung and Ruge revisited. Journalism Studies, 2(2), 261-280.
Hawkins, V. (2011). Peace process or just peace deal? The media's failure to cover peace. In I. S. Shaw, J. Lynch, \& R. A. Hackett (Eds.), Expanding peace journalism: Comparative and critical approaches (pp. 261-84). Sydney: Sydney University Press.

Herman, E., \& Chomsky, N. (2002). Manufacturing consent: The political economy of mass media. New York: Pantheon.

Howard, R. (2003). Handbook on conflict sensitive journalism. Denmark: International Media Support and Institute for Media, Policy and Civil Society. Retrieved from http://ict4peace.org/handbook-on-conflictsensitive-journalism-ross-howard-2003

Hume, M. (1997). Whose war is it anyway? The dangers of the journalism of attachment. London: LM Inform.

Ife, J. (2007). Human rights and peace. In C. Webel \& J. Galtung (Eds.), Handbook of peace and conflict studies (pp. 160-172). New York: Routledge.

Kant, I. (1963/1784). Idea for a universal history from a cosmopolitan point of view. Retrieved from www.marxist.org/refrence/subject/ethics/kant/univ ersal-history.htm

Keeble, R. L. (2010). Peace journalism as political practice: A new, radical look at the theory. In R. L. Keeble, J. Tulloch, \& F. Zollmann (Eds.), Peace journalism, war and conflict resolution (pp. 49-68). UK: Peter Lang.

Keeble, R. L., Tulloch, J., \& Zollmann, F. (2010). Introduction: Why peace journalism matters. In R. L. Keeble, J. Tulloch, \& F. Zollmann (Eds.), Peace journalism, war and conflict resolution (pp. 335-352). UK: Peter Lang.

Kempf, W. (2003). Constructive conflict coverage-A social-psychological research and development program. Conflict \& Communication Online, 2(2). Retrieved from http://www.cco.regener-online.de

Kempf, W. (2007). Peace journalism: A tightrope walk between advocacy journalism and constructive conflict coverage. Conflict \& Communication Online, 6(2). Retrieved from http://www.cco.regeneronline.de

Kidd, D., \& Rodriguez, C. (2010). Introduction. In D. Kidd, C. Rodriguez, \& L. Stein (Eds.), Making our media: Global initiatives toward a democratic public sphere (Vol. 2, pp. 189-206). Cresskill, NJ: Hampton Press.

Knightley, P. (2000). The first casualty: The war correspondent as hero and myth-maker from the Crimea to Kosovo. London: Prion Books.

Larssen, I. (2009). Peace and human rights: A comparative analysis on the role of human rights in Norwegian peace processes in Sudan (Unpublished Masters Thesis). Faculty of Social Sciences, University of Tromso, Norway.

Lederach, J. P. (1997). Building peace-Sustainable reconciliation in divided societies. Washington: United States Institute of Peace Press.

Lederach, J. P. (2003). Defining conflict transformation. 
Restorative Justice Online. Retrieved from http:// www.restorativejustice.org/10fulltext/lederach

Lesage, F., \& Hackett, R. A. (2013). Between objectivity and openness-The mediality of data for journalism. Media and Communication, 1(1), 39-50.

Lynch, J. (2003). Journalists need to think: A reply to David Loyn. Open Democracy. Retrieved from http:// www.opendemocracy.net/media-journalismwar/ article_1037.jsp

Lynch, J. (2010). Propaganda, war, peace and the media. In R. L. Keeble, J. Tulloch, \& F. Zollmann (Eds.), Peace journalism, war and conflict resolution (pp. 69-83). UK: Peter Lang.

Lynch, J. (2013). A global standard for reporting conflict. NY: Routledge.

Lynch, J., \& Galtung, J. (2010). Reporting conflict: New directions in peace journalism. Australia: University of Queensland Press.

Lynch, J., Hackett, R. A., \& Shaw, I. S. (2011). Introduction. In I. S. Shaw, J. Lynch, \& R. A. Hackett (Eds.), Expanding peace journalism: Comparative and critical approaches (pp. 7-31). Sydney: Sydney University Press.

Lynch, J., \& McGoldrick, A. (2005). Peace journalism. Stroud: Hawthorn Press.

Mandelzis, L. (2007). Representations of peace in news discourse: Viewpoint and opportunity for peace journalism. In D. Shinar \& W. Kempf (Eds.), Peace journalism: The state of the art (pp. 97-110). Berlin: Regener.

Matheson, D., \& Allan, S. (2010). Social networks and the reporting of conflict. In R. L. Keeble, J. Tulloch, \& F. Zollmann (Eds.), Peace journalism, war and conflict resolution (pp. 173-192). UK: Peter Lang.

McGoldrick, A. (2007). War journalism and 'objectivity'. In D. Shinar \& W. Kempf (Eds.), Peace journalism: The state of the art (pp. 17-25). Berlin: Regener.

McGoldrick, A. (2011). Empathy and ethics: Journalistic representation and its consequences. In I. S. Shaw, J. Lynch, \& R. A. Hackett (Eds.), Expanding peace journalism: Comparative and critical approaches (pp. 122-144). Sydney: Sydney University Press.

Messman, T. (2001). Justice journalism: Journalist as social agent of social change. Media File, 20(4). Retrieved from http://www.media-alliance.org/media file/20-4/justice.html

Mogekwu, M. (2011). Conflict reporting and peace journalism. In search of a new model: Lessons from the Nigerian Niger Delta crisis. In I. S. Shaw, J. Lynch, \& R. A. Hackett (Eds.), Expanding peace journalism: Comparative and critical approaches (pp. 239-260). Sydney: Sydney University Press.

Newman, N. (2011). Mainstream media and the distribution of news in the age of social discovery. Oxford: Reuters Institute for the study of journalism. Retrieved from: https://reutersinstitute.politics.ox.ac. uk/sites/default/files/Mainstream\%20media\%20and \%20the\%20distribution\%20of\%20news\%20in\%20the \%20age\%20of\%20social\%20discovery_0.pdf

Nordenstreng, K. (2001). Something to be done: Transitional media monitoring. Transitional Broadcasting Studies Journal, Spring edition. Retrieved from www.tbsjournal.com/Archives/Spring01/nordenstre ng.html

Rai, M. (2010). Peace journalism in practice-Peace news: For non-violent revolution. In R. L. Keeble, J. Tulloch, \& F. Zollmann (Eds.), Peace journalism, war and conflict resolution (pp. 207-238). UK: Peter Lang.

Robie, D. (2010). Conflict reporting in the South Pacific: Why peace journalism has a chance. Journal of Pacific Studies, 32(20), 221-240.

Robie, D. (2013). 'Four Worlds' news values revisited: A deliberative journalism paradigm for Pacific media. Pacific Journalism Review, 19(1), 84-110.

Roland, A. (1994). Cruelty and civilization: The Roman games. London: Routledge.

Ross, D. S. (2007). (De-)constructing conflict: A focused review of war and peace journalism. In D. Shinar \& W. Kempf (Eds.), Peace journalism: The state of the art (pp. 53-74). Berlin: Regener.

Schirch, L. (2002). Human rights and peacebuilding: Towards justpeace. Paper presented to $43^{\text {rd }}$ Annual International Studies Association Convention, New Orleans, Louisiana, March 2002.

Shaw, I. S. (2011). Human rights journalism: A critical conceptual framework of a complementary strand of peace journalism. In I. S. Shaw, J. Lynch, \& R. A. Hackett (Eds.), Expanding peace journalism: Comparative and critical approaches (pp. 96-121). Sydney: Sydney University Press.

Shaw, I. S., Lynch, J., \& Hackett, R. A. (2011). Expanding peace journalism: Comparative and critical approaches. Sydney: Sydney University Press.

Shinar, D. (2007). Peace journalism: The state of the art. In D. Shinar \& W. Kempf (Eds.), Peace journalism: The state of the art (pp. 199-210). Berlin: Regener.

Siebert, F., Peterson, T., \& Schramm, W. (1963). Four theories of the press. Urbana: University of Illinois Press.

Suchenwirth, L., \& Keeble, R. L. (2011). Oligarchy reloaded and pirate media: The state of peace journalism in Guatemala. In I. S. Shaw, J. Lynch, \& R. A. Hackett (Eds.), Expanding peace journalism: Comparative and critical approaches (pp. 168-190). Sydney: Sydney University Press.

Tehranian, M. (2002). Peace Journalism: Negotiating global media ethics. Harvard International Journals of Press/Politics, 7(2), 58-83.

Tehranian, M. (2007). Preface. In D. Shinar \& W. Kempf (Eds.), Peace journalism: The state of the art (pp. 78). Berlin: Regener.

The Economist. (2011, July 7). Bulletins from the future, special report by T. Standage. Retrieved from http:// www.economist.com/node/18904136 
Tivona, E. J. (2011). Globalisation of compassion: Women's narratives as models for peace journalism. In I. S. Shaw, J. Lynch, \& R. A. Hackett (Eds.), Expanding peace journalism: Comparative and critical approaches (pp. 317-344). Sydney: Sydney University Press.

UNESCO, (1978). Declaration on fundamental principles concerning the contribution of the mass media to strengthening peace and international understanding, to the promotion of human rights and to countering racialism, apartheid and incitement of war. Retrieved from http://www.unesco.org/en/ev.phpURL_ID=13176\&URL_DO=DO_TOPIC\&URL_SECTION $=201$. html

Ury, W. (2001). Must we fight? From the battlefield to the schoolyard: A new perspective on violent conflict and its prevention. New York: John Wiley \& Sons.

van Dijck, J., \& Poell, T. (2013). Understanding social media logic. Media and Communication, 1(1), 2-14.

Walzer, M. (1992). Just and unjust wars: A moral argument with historical illustrations (2nd ed.). New York: Basic Books.

Ward, S. J. A. (2005). The invention of journalism ethics: The path to objectivity and beyond. Montreal: McGill Queen's University Press.

Wolfsfeld, G. (1997). Media and political conflict: News from the Middle-East. Cambridge: Cambridge University Press.

Wolfsfeld, G., Alimi, E. \& Kailani, W. (2008). News media and peacebuilding in asymmetrical conflicts: the flow of news between Jordon and Israel. Political Studies, 56(2), 374-398.

Zogby, J. J. (September 17, 2003). Ten years later, the world is upside down. Arab News. Retrieved from http://www.arabnews.com/node/237446

\section{About the Author}

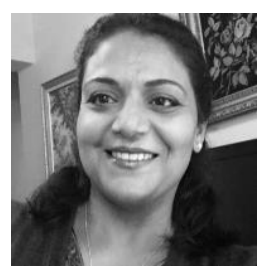

Dr. Rukhsana Aslam

Rukhsana Aslam is a journalist-turned-academic from Pakistan now living in New Zealand. She has her doctorate on the role of media in conflict with focus on integrating peace journalism in the journalism curriculum, from the Auckland University of Technology (AUT), New Zealand. She has been closely associated with the Pacific Media Centre at AUT and was the recipient of Asia-New Zealand Foundation's Asian Journalism Fellowship Award in 2011. 